\title{
Twenty Years of Basic Vocational Education Provision in Spain: Changes and Trends ${ }^{1}$
}

\author{
Fernando Marhuenda-Fluixá* \\ University of Valencia \\ Facultat de Filosofia i Ciències de l'Educació \\ Av. Blasco Ibáñez, 30 - 46010 Valencia, Spain \\ E-mail: marhuend@uv.es

\section{Francesca Salvà} \\ University of les Illes Balears \\ Edifici Guillem Cifre de Colonya - Campus universitari \\ Cra. de Valldemossa, km 7,5 - 07122 Palma (Illes Balears), Spain \\ E-mail: f.salva@uib.es
}

\author{
Almudena A. Navas Saurin, Miriam Abiétar López \\ University of Valencia \\ Facultat de Filosofia i Ciències de l'Educació \\ Av. Blasco Ibáñez, 30 - 46010 Valencia, Spain \\ E-mail: anavas@uv.es, miriam.abietar@uv.es \\ * Corresponding author
}

\begin{abstract}
Our contribution attempts to review basic vocational education programmes in Spain over the past 25 years. We intend to compare the evolution of these programmes in terms of conception and conditions of delivery in order to find out how different they are as skill-formation and remedial systems, as well as analysing how different political views have an impact upon such provision. We will focus on the current programmes in two regions in Spain where tourism is the main economic strength and source of employment. The authors have been working on several research projects investigating these issues since the late 1990s and we are currently working on two of them.
\end{abstract}

Keywords: mixed methods, initial vocational education and training, competence development, policy, history, school-to-work transition

\footnotetext{
Part of this paper is based on work developed under two projects: LLP Leonardo da Vinci Projekt LLP-LDV-TOI-2013-LT-0125 "Application of apprenticeship in the vocational integration of socially disadvantaged youth" (APPRENTSOD). And "Success and dropout pathways in vocational training/education in Spain" (Project Reference: EDU2013-42854-R), funded by the Spanish Ministry of Economy and Competitiveness within the national Programme of Research, Development and Innovation.
} 


\section{Bibliographical notes:}

Dr Fernando Marhuenda is Professor in Didactics at the School of Philosophy and Education at the University of Valencia, Spain. His research interests focus on vocational education, workplace learning, transitions between education and work, and education and training in contexts of vulnerability. He has conducted research since 1996 on PGS and PCPI, and is currently researching the development of FPB.

Dr Francesca Salvà Mut has been Associate Professor since 1996 in the Department of Applied Pedagogy and Educational Psychology at the Balearic Islands University (UIB). She has been a visiting researcher at, among others, Universite Laval (Quebec, Canada), Université du Québec à Montreal (Quebec, Canada), and the Centre for the Study of Education and Work, Ontario Institute for Studies in Education of the University of Toronto (Toronto, Canada).

Dr Almudena Navas is lecturer and researcher at the Institute of Education at the University of Valencia, Spain. Her research interests focus on school-to-work transition, learning, and assessment in vocational education.

Míriam Abiétar, MA, is a research assistant at the School of Philosophy and Education at the University of Valencia, Spain. Her research interests focus on vocational education and school-to-work-transition. She is currently doing her $\mathrm{PhD}$, based on the analysis of educational contexts for groups in a situation of social vulnerability within a theoretical framework of social justice.

\section{Introduction}

The beginning of the modernisation of the Spanish VET system can be identified in 1990. It has evolved significantly since then, within a European frame of reference. With the raising of the school-leaving age to 16 , a new provision for the lowest level of qualification was offered in 1994, intended particularly for students classified as low achievers in secondary schools and for young people under difficult circumstances. These programmes were named PGS Programas de Garantía Social (Social Guarantee Schemes), and they lasted until 2007, when they were replaced

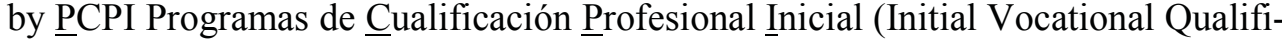
cation Programmes). These more recent programmes, with some differences but aimed at the same population, were reshaped again in 2013 and they are being offered for the first time in 2014/2015.

Our contribution starts with a short review of the literature on such programmes. Then we intend to compare the evolution of all three programmes in terms of conception and conditions of delivery, in order to evaluate how they function in skill formation and as remedial systems. We will also analyse how different political views and governance rationales have an impact upon such provision.

As researchers, our study of such measures has been prompted by academic as well as social interest. It is our assumption that every time these measures have been reshaped, along with the transformations in labour market regulations, schooling and working conditions, they have moved between re-education and social control. The struggle between these two trends in every reform affects both students and teachers, and it is not an innocent struggle. In this article, by analysing data and literature produced over the past two decades, we intend to provide evidence of such imbalances, and to show that under the banner of compensatory edu- 
cation there are veiled political aims. Specifically we will analyse the current programmes in two regions in Spain where tourism is the main economic strength and source of employment. This is something the authors have been working on since the late 1990s in several research projects and on which we are also currently working.

\section{From PGS to PCPI to FPB: Normative changes and shifting trends.}

Since 1990 four different laws have been passed in Spain changing the structure and purpose of the overall general education system and entailing different conceptions of the role of secondary education, its universal scope, and the debate about comprehensive versus elitist education provision.

The raising of the school leaving age from 14 to 16 implied the most significant change in the system. Suspension had been an accepted practice until 1990, allowing teachers to get rid of bad or uninterested students, but the law passed that year turned suspension into retention. Compensatory programmes disappeared, and they were replaced by support measures at both individual and group level. The most remarkable measure in that law affecting secondary education, which only started being offered in 1994, was known as Social Guarantee Schemes (PGS). These could be offered by secondary schools, municipalities, or Non Governmental Organisations (NGOs), and the latter two options were preferred by the Valencian region, while most regions of Spain chose schools to offer the schemes. PGS had three parallel aims: to foster personal development of those young people who had shown strong disaffection with school; to help them re-enter the educational system; and to provide them with some low-qualified training that might help them choose an occupational field.

In 2002 a new law was passed, even if it was never applied. It followed a bitter debate on the role of secondary education, and it replaced PGS for the new Initial Occupational Programmes (PIP). This implied a move away from the aims of PGS, for it attempted to provide all young people attending programmes with the Certificate of Compulsory Secondary Education. Also in 2002, another law was passed on vocational qualifications and vocational education; this has been the only ruling on vocational education and training (VET) and was the result of a broad consensus.

However, general elections in 2004 prevented the development of PIP. The new Government passed a new law in 2006, replacing PIP with Initial Vocational Qualification Programmes (PCPI). These aimed to provide the new vocational qualifications (level 1) established by the 2002 law on vocational qualifications and vocational education even though PCPI allowed for the achievement of the Certificate of Compulsory Secondary Schooling. This is one reason why many such programmmes were devolved to the school system in the Valencian region and taken away from municipalities and NGOs.

By 2006, early school-leaving was already a major concern for the Spanish Department of Education, because this new indicator left the country in a very bad position in any international comparison. PCPI were conceived as one more measure to tackle this problem. That was the reason to introduce another change: the chance to extend the programme to a second year, together with a strong curricular regulatory framework for both academic and vocational subjects. At this point, the aim of fostering personal development among young people had fallen away. The extension to a second year, together with the weight of a curriculum prescribed to a greater extent than previously,was a significant change. It also became possible to 
register in such a programme at the age of 15 , if no other opportunities were envisaged for the young person.

In 2012 the next (and last, to date) education law was passed, again in the wake of a change of government, with the aim of restoring as much as possible some of the ideas behind the 2002 law but with an even stronger conservative and neoliberal drive. This led to the creation of a new programme, known as Basic Vocational Education (FPB Formación Profesional Básica in Spanish). Such programmes can only be delivered by secondary schools; only in rare cases, such as the Valencian region, will municipalities and NGOs be able to offer a different programme, named Basic Qualification Programmes (PCPB), because provision over almost two decades by NGOs and municipalities has proved adequate.

The entry age has been lowered to 15 for all students (no longer as an exceptional measure) and those who attend it will not receive the Certificate of Compulsory Secondary Education but a VET level 1 qualification instead. In fact, such a measure drops the aim of encouraging young people to re-enter the education system and instead focuses only on gaining the lowest vocational qualification. It can be considered a segregation measure, for it is offered within the age of compulsory schooling and ignores the principle of comprehensivity that has been embedded in the system since 1990. This also introduces a rupture in the consensus around VET that has been a feature of the system since the late 1980s and which was based, among other features, on the agreement that graduation from compulsory education was necessary before embarking either on the academic or the vocational pathway at post-compulsory level.

\section{Balance of the offer/demand of PGS, PCPI and FPB: Data from two re- gions.}

The data that we will analyse and present in this section in order to discuss supply and demand are approximate, due to the nature of the statistics available. They are data collected by each of the departments of education within regional governments in Spain (of which there are 17, though only 15 of them have full control over education, as the autonomous cities of Ceuta and Melilla are directly managed by the State Department of Education). These data are not made public by all regional governments. Once they have been collected by the State Department of Education, they are collated and published for the education community in the form of raw data. But this process takes almost two years as they are only published following analysis, recommendations and reviews by the State School Council, the body in charge of editing and publishing them.

An initial idea of the potential demand for these programmes emerges from an analysis of the rate of students who did not achieve the Graduate of Compulsory Education (GESO is the Spanish acronym that we will use hereafter), as these students are the intended beneficiaries of such programmes. Such a percentage comes out of the gross rate indicator of students with $\mathrm{GESO}^{2}$ and the percentage of students who leave compulsory education without the GESO.

2 The gross percentage of students with GESO is calculated out of the relation "between students in compulsory secondary education achieving the GESO and the total among the population with the theoretical age to start the final year of compulsory secondary education (15 years old).” (Ministerio de Educación, Cultura y Deporte, 2013, 100). 
The percentage of students with GESO was $75.1 \%$ of the whole cohort in the school year $2011-12^{3}$ (80.6\% for women and $69.9 \%$ for men). The situation in the Valencian and Balearic regions is worse. In Valencia this percentage was $63 \%$ (56.2\% of men and $70.3 \%$ of women) and in the Balearics, the figure was $67.4 \%$ $(61.5 \% \text { in men and } 73.6 \% \text { in women })^{4}$.

The analysis of the development of such percentage shows that starting from the first cohort of students with GESO (school year 1999-2000 ${ }^{5}$ ) up to the current school year, the percentage remains stable with only slight variations (Salvà, 2003). Global percentage in the school year $1999-2000$ was $73.4 \%$ (1.7 points below current data), out of which $81.3 \%$ corresponded to women $(0.7$ points above current data), and $65.9 \%$ corresponded to men (4 points below current data).

Another interesting approach focuses on the percentage of young people who abandon compulsory secondary education without graduating. Recent data (school year $2011-12)$ show that $22 \%$ (26.8\% of men and $17.2 \%$ of women) of those who left compulsory secondary education did not achieve GESO.

This is approximately 90.141 students $^{6}$. The Valencian region and the Balearic Islands have a higher volume of students under these circumstances, with percentages of $33.1 \%$ (38.2\% of men and $28 \%$ of women) and $22.9 \%$ (32.9\% of men and $20.7 \%$ of women) respectively ${ }^{7}$. This implies a potential demand for PCPI (the programme in course in that school year) of more than one out of every five Spanish young people. In the case of the Balearic Islands, that proportion is a little more than one out of every four, and for the Valencian region almost one out of every three.

The fact that both the Valencian region and Balearic Islands are among the regions in a difficult situation is closely linked to the fact that both are located on the Mediterranean coast and are economically reliant on tourism and related sectors, particularly construction. The availability of employment for young people without qualifications attracts them into the labour market, a situation exacerbated by the lack of public policies aimed at retaining students. There were no policies either to facilitate mixed situations of education and employment or to facilitate the return to education of unqualified young people (Adame \& Salvà, 2010; Salvà-Mut \& Sureda-Negre, 2012; Salvà-Mut, Comas-Forgas \& Oliver-Trobat, 2014).

The financial crisis that started in 2008 has had a severe impact on employment, with young people being particularly badly affected in Spain. This of course has meant that percentagees from employment have diminished while unemployment costs have increased, as shown in Table 1 . The impact has been

3 The most recent school year in which such data have been published at the time of writing this text.

4 Data produced from: http://www.mecd.gob.es/dms/mecd/servicios-alciudadanomecd/esta-disticas/educacion/indicadores-publicaciones-sintesis/cifraseducacionespana/2015-/C2.pdf

5 In the school year 1999-2000 the first full cohort of the new LOGSE system left school. LOGSE is the law that extended comprehensive compulsory schooling to the age of 16.

6 According to the report of the Consejo Escolar del Estado (2014), 319,591 students successfully achieved GESO in the 2011-12 school year. If we relate this information to the percentages of graduating and non-graduating students, we find that 90,141 did not graduate (achieve GESO).

7 Data taken from: http://www.mecd.gob.es/dms/mecd/servicios-al-ciudadano$\mathrm{mecd} /$ estadis-ticas/educacion/indicadores-publicaciones-sintesis/cifras-educacionespana/2015/-D3.pdf 
particularly intense in regions dependent on tourism and associated sectors, such as Valencia and the Balearic Islands.

Table 1: Youth unemployment and employment rates: the impact of the economic crisis. Source (data ellaborated by the authors out of the following sources)

\begin{tabular}{|l|l|l|l|l|l|l|l|l|l|l|l|l|}
\hline \multicolumn{4}{|l|}{ Unemployment rate (under 25) } & \multicolumn{9}{l|}{ Employment rate (under 25) } \\
\hline & $2007^{8}$ (3rd Quarter) & 2013 & (3rd Quarter) & \multicolumn{2}{l|}{2007 (3rd Quarter) } & 2013 (3rd Quarter) \\
\hline & All & Male & Fem. & All & Male & Fem. & All & Male & Fem. & All & Male & Fem. \\
\hline Spain & 17.87 & 15.18 & 21.18 & 54.14 & 53.96 & 54.35 & 45.38 & 50.61 & 39.90 & 19.89 & 20.88 & 18.86 \\
\hline Valencia & 17.80 & 13.92 & 22.47 & 55.13 & 59.14 & 50.76 & 48.68 & 54.42 & 42.67 & 20.43 & 18.99 & 21.94 \\
\hline $\begin{array}{l}\text { Balearic } \\
\text { Islands }\end{array}$ & 7.29 & 5.04 & 10.04 & 32.79 & 28.25 & 37.96 & 56.85 & 63.15 & 50.36 & 35.36 & 39.69 & 30.91 \\
\hline
\end{tabular}

Notes. http://www.ine.es/dynt3/inebase/es/index.htm?padre=990\&capsel=993, http://www.ine.es/dynt3/inebase/es/index.htm?padre=990\&capsel $=994$

While the situation for young people in the labour market has worsened, retention in the school system has increased for those who are now aged between 20 and 24, as data on early school leaving (ESL) show in Table 2.

Table 2: Early school leaving rate and education level of young people in Spain: impact of the crisis

\begin{tabular}{|c|c|c|c|c|c|c|c|c|c|c|c|c|}
\hline & \multicolumn{6}{|c|}{ ESL rate } & \multicolumn{6}{|c|}{$\begin{array}{l}\text { Education level (percentage of young people } \\
\text { between } 20 \text { and } 24 \text { who have successfully } \\
\text { completed secondary education) }\end{array}$} \\
\hline & \multicolumn{3}{|c|}{2008} & \multicolumn{3}{|l|}{2013} & \multicolumn{3}{|c|}{2008} & \multicolumn{3}{|c|}{2013} \\
\hline & All & Male & Fem. & All & Male & Fem. & All & Male & Fem. & All & Male & Fem. \\
\hline Spain & 31.7 & 38.0 & 25.1 & 23.8 & 27.2 & 19.8 & 60.3 & 52.7 & 58.4 & 63.8 & 58.4 & 69.4 \\
\hline Valencia & 32.6 & 38.2 & 26.8 & 21.7 & 26.2 & 17.0 & 59.6 & 52.9 & 66.5 & 65.6 & 59.7 & 71.6 \\
\hline $\begin{array}{l}\text { Balearic } \\
\text { Islands }\end{array}$ & 42.5 & 48.1 & 36.7 & 29.8 & 33.6 & 25.8 & 49.3 & 41.5 & 57.1 & 55.0 & 50.8 & 59.2 \\
\hline
\end{tabular}

Notes. Source (data ellaborated by the authors out of the following sources): http://www.mecd.gob.es/dms/mecd/servicios-al-ciudadanomecd/estadisticas/educacion/indicadores-publicaciones-sintesis/cifras-educacion-espana/2015/C2.pdf

In this context, both PGS and PCPI have contributed to the education of young people who do not have the Certificate of Secondary Education with the aim of equipping them with a Level 1 VET and, if possible, enabling them to achieve GESO.

Official statistics allow us to analyse participation across the country and in both regions from 1996-1997 to 2012-2013. As can be seen in Table 3 and Graphs 1 to 3, there was an increase in Spain until 2002-2003. From then on, the situation remains stable until 2008-2009, when the number of students rises again to 84,217

82007 is used as a reference because it is the year prior to the start of the crisis. 2013 is the most recent year for which we have available data. Given the seasonal nature of the tourist sector, data from the third quarter correspond to the period with highest employment rates and lowest unemployment rates. 
in 2011-2012, after which it declines. The most recent information points to a provision rate of the programme for all of Spain of $93.2 \%$.

Data in the Balearic Islands and Valencia follow the same trend except that in both cases the positive growth since 2002-2003 is far more accelerated than for Spain as a whole, and that the growth in the number registering in 2011-12 remains positive.

Table 3: Increase in number of students in PGS and PCPI

\begin{tabular}{|r|r|r|r|r|r|}
\hline & $1996-97$ & $2002-03$ & $2008-09$ & $2011-12$ & $2012-13$ \\
\hline SPAIN & 17,229 & 46,281 & 54,914 & 84,217 & 84,009 \\
\hline BALEARIC ISLANDS & 200 & 460 & 1,072 & 2,113 & 2,224 \\
\hline VALENCIAN REGION & 40 & 1,859 & 3,210 & 10,493 & 11,220 \\
\hline
\end{tabular}

Notes. Source: (data ellaborated by the authors out of the following sources): http://www.mecd.gob.es/servicios-al-ciudadano-mecd/ca/estadisticas/educacion/indicadores-publicaciones-sintesis/cifras-educacion-espana.html.

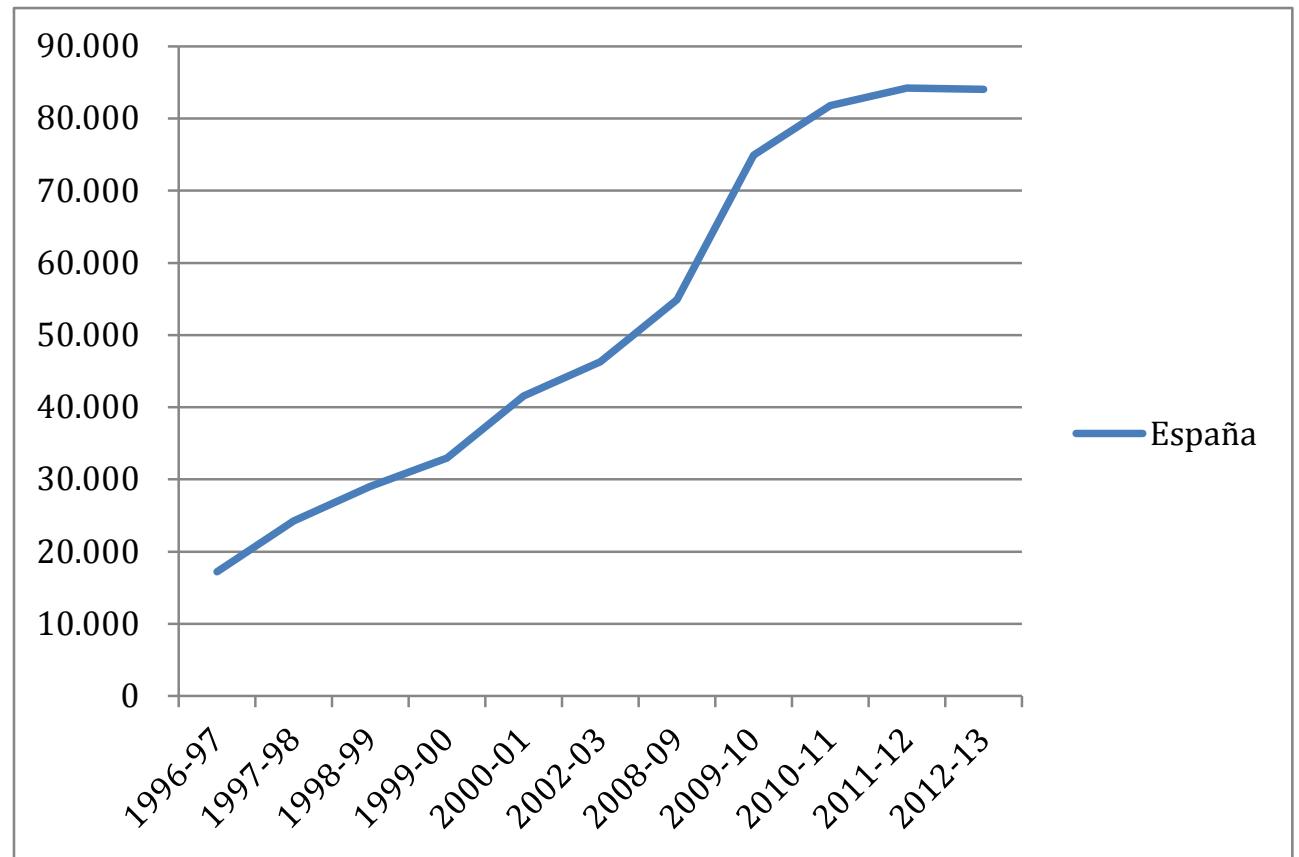

Notes. Source: (data ellaborated by the authors out of the following sources): http://www.mecd.gob.es/servicios-al-ciudadano-mecd/ca/estadisticas/educacion/indicadores-publicaciones-sintesis/cifras-educacion-espana.html.

Figure 1: Students in PGS and PCPI (Spain)

9 This calculation was made from the relation between the number of those who did not ahieve GESO in 2011-12 $(90,141)$ and the number of those registered in such programmes in 2012-13 (84,009). 


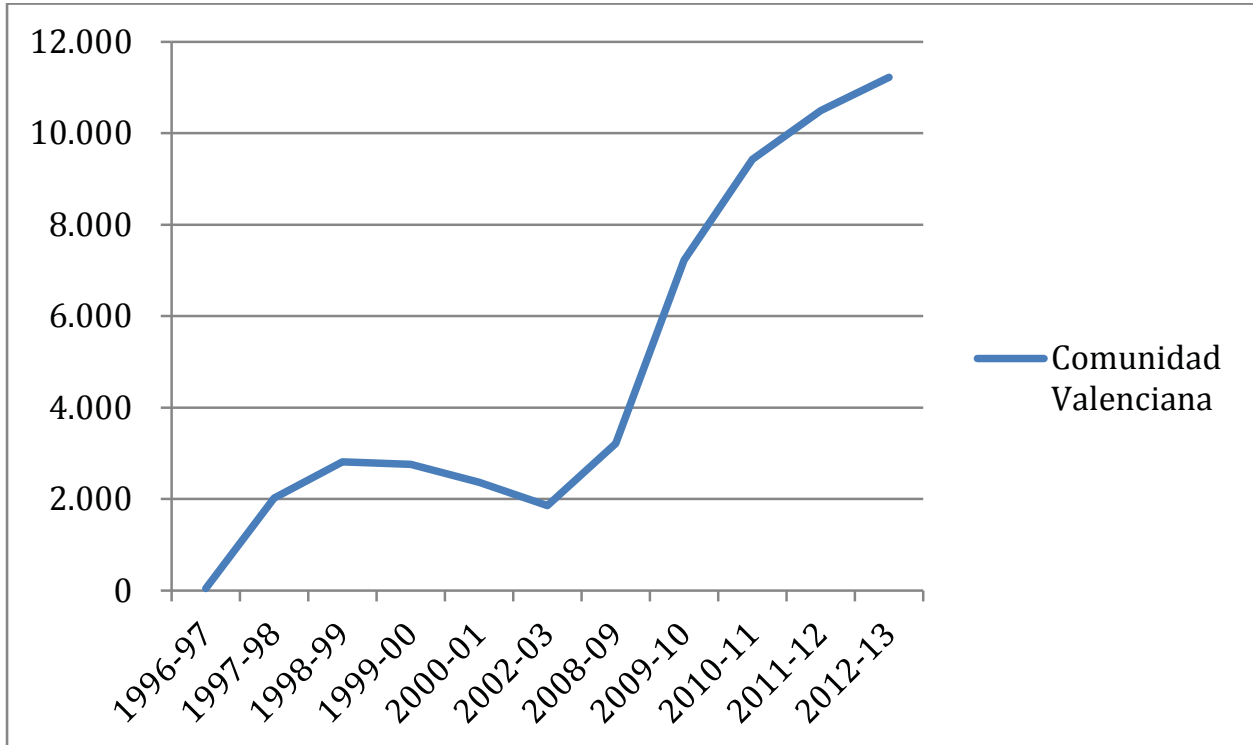

Notes. Source: (data ellaborated by the authors out of the following sources): http://www.mecd.gob.es/servicios-al-ciudadano-mecd/ca/estadisticas/educacion/indicadores-publicaciones-sintesis/cifras-educacion-espana.html.

Figure 2: Students in PGS and PCPI (Valencian Region)

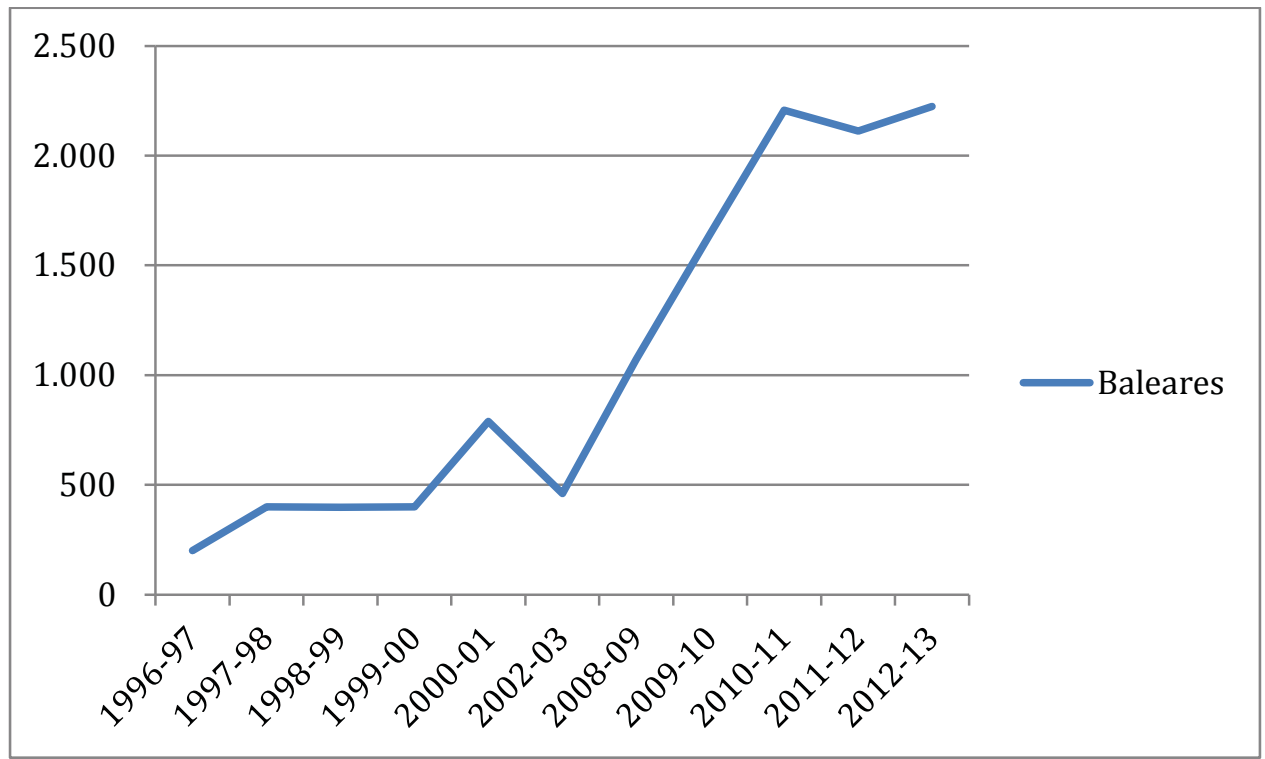

Notes. Source: (data ellaborated by the authors out of the following sources): http://www.mecd.gob.es/servicios-al-ciudadano-mecd/ca/estadisticas/educacion/indicadores-publicaciones-sintesis/cifras-educacion-espana.html.

\section{Figure 3: Students in PGS and PCPI (Balearic Islands)}

If we introduce analysis according to sex, it can be seen that men participate more throughout the period. In the first school year of reference, $74 \%$ of those registered were men, compared with $26 \%$ of women. The sex gap decreases in the following years to become stable in a proportion of $66-67 \% / 34-33 \%$ in the period $2003-04$ to 
2007-08, after which it increases slightly again. In 2008-09, the proportion is $68 \%$ $32 \%$ and, from then on up to now, it remains in a proportion of $69 \% / 31 \%$. Data for both the Balearic Islands and the Valencian region show a similar trend.

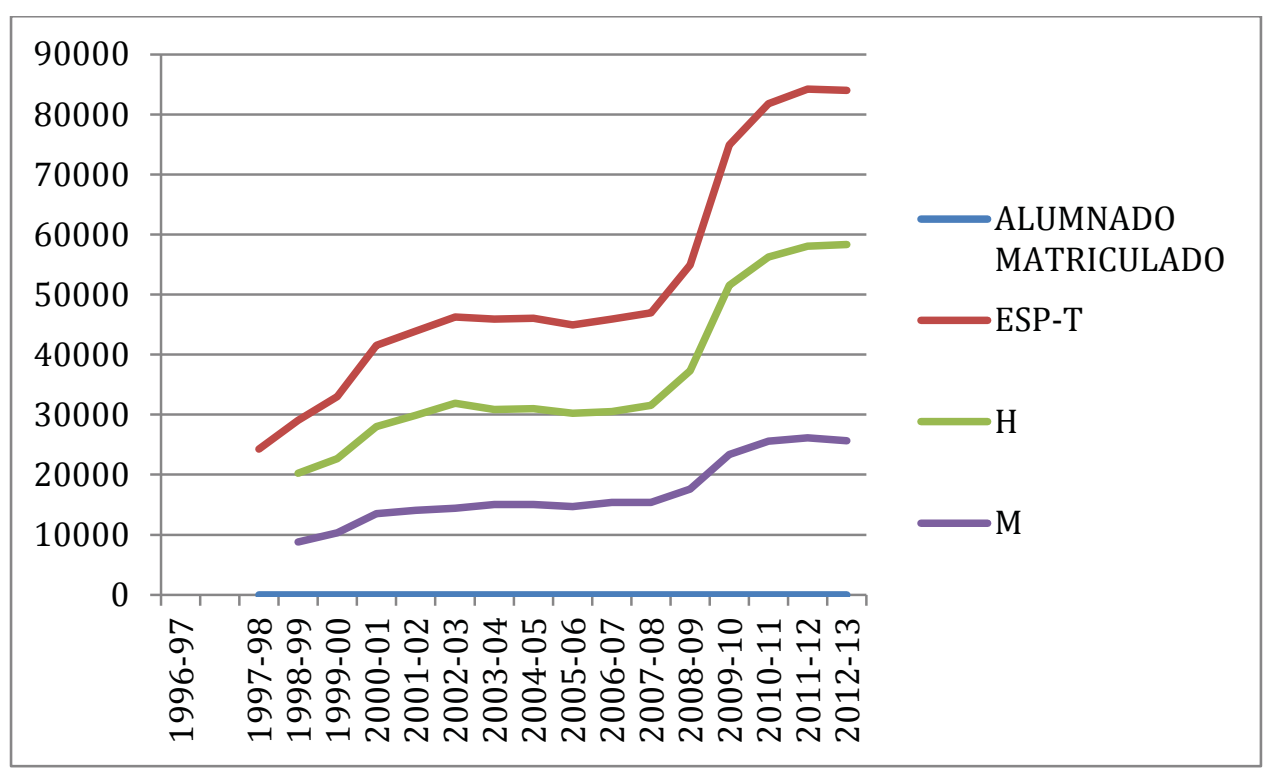

Notes. Global data and by sex. Spain. Where H means men, M means women, ESP-T means total and 'alumnado matriculado' means registered students.

\section{Figure 4: Number of students in PGS and PCPI}

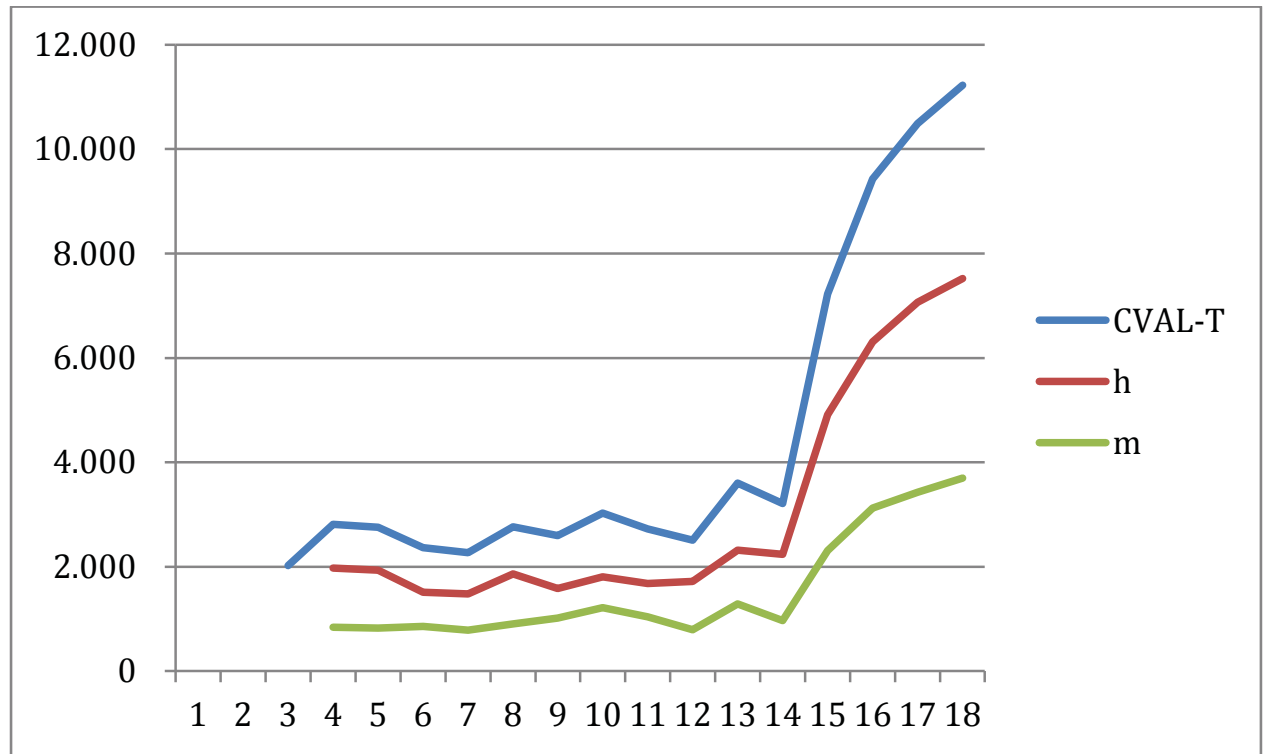

Notes. Global data and by sex. Valencian region. Where $H$ means men, $M$ means women, CVAL-T means total registered students.

Figure 5: Number of students in PGS and PCPI 


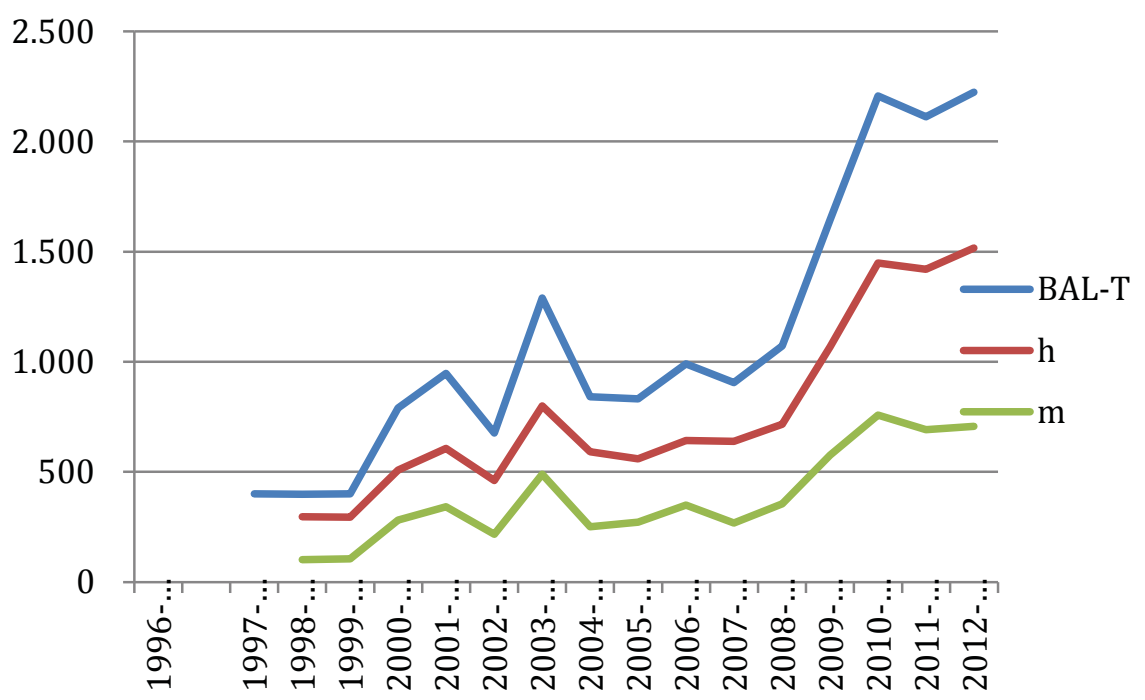

Notes. Global data and by sex. Balearic Islands region. Where $H$ means men, $M$ means women, BAL-T means total number of registered students.

\section{Figure 6: Number of students in PGS and PCPI.}

Analysis of data for the year 2012-2013 ${ }^{10}$ allows further investigation of the features of participation in the programmes. Valencia is the region with the second highest number of students enrolled in PCPI, while the Balearic Islands are in 12th position, with $15.2 \%$ and $2.6 \%$ of all students in PCPI respectively. Students come mainly from compulsory education $(68.1 \%)$, while $13.9 \%$ were out of school, $16.5 \%$ in other situations and $1.5 \%$ in special education. In Valencia and the Balearic Islands, the percentage of students coming from compulsory education is higher, at $81.8 \%$ and $89.7 \%$ respectively.

We can approach the provision of such programmes by age by analysing neto rates of schooling ${ }^{11}: 16$ and 17 -year-olds were most likely to participate $(6.8 \%$ and $6.7 \%$ respectively), while for 18 -year-olds the percentage is $7 \%$, for 15 year-olds, $1.5 \%$, and for 19 -year-olds, $1 \%$. In the case of the Valencian region, the neto rate is higher than average by the ages of 15, 16 and 17, and inferior by the ages of 18 and 19. In the Balearic Islands, the proportion is higher by 15 and 16, while in the following years it has similar or slightly inferior values compared to the average.

Academic results are reflected in the gross rate of those who finish the compulsory modules ${ }^{12}$ and the gross rate of those who finish the voluntary modules in order to attain the $\mathrm{GESO}^{13}$. In relation to the compulsory modules, the global percentage for Spain is $8 \%$, while it is $11.5 \%$ in the Balearic Islands and $6.8 \%$ in

10 Information sourced from: http://www.mecd.gob.es/dms/mecd/servicios-al-ciudadano$\mathrm{mecd} /$ estadisticas/educacion/indicadores-publicaciones-sintesis/cifras-educacionespana/2015/D4.pdf.

11 Relation between the total numbers of students of a certain age registered in this kind of education and the population of that age group.

12 Proportion of students accomplishing those studies, disregarding age, compared with the cohort of 17-year-olds (taken as the theoretical age for finishing such studies).

13 Idem to the previous. 
the Valencian region. For the voluntary modules, the global percentage for Spain is $3.3 \%$, compared to $3.9 \%$ in both the Balearic Islands and the Valencian region.

\section{Research review}

PGS have been operating since 1994 and PCPI since 2006, and even if they have not received a great deal of attention from education researchers, we can identify at least three strands of research.

The first has a sociological bias and focuses on school failure and transition systems. The Group for Research in Education and Work (GRET14) has carried out extensive research on transitions from youth to adulthood from a biographical perspective, and attributes the changes produced in transitions to the context of informational capitalism (Casal et al., 2006a). In this sense, they defend the biographical approach in "Sociology of Youth" (Casal et al. 2006b), discussing the biographical dimension of the study of transitions, as well as the need to include in this analysis not only the political structure, but also the institutional actions that influence the way individuals develop their transitions. Therefore, they approached transitions as a combination of individual choices strongly conditioned by socioeconomic variables as well as by regional development interventions. They also considered changes in labour markets, which have become segmented as well as increasingly precarious. This theoretical positioning is the framework for their extensive empirical work, where they have confirmed the differential modalities of transitions to adulthood proposed in their own earlier studies (Casal, 1997; Casal et al., 2004).

A second strand has emerged from psychological research, mainly developmental psychology (Zacarés, 1998, Llinares and Zacarés, 2006). These studies consider themes such as developmental processes, access to adult life, common adolescent issues, individual expectations, characteristics and capabilities. There has also been extensive analysis of the construction of identities, particularly occupational identities.

However, the main perspective of research on PGS and PCPI is educational. Most of the studies have a regional scope, due to the different normative regulations in each of the Spanish regions. Even if there have not been studies of the whole of Spain, we can find studies on the Balearic Islands (Salvà, 2001, 2002), Valencia (Aparisi, 1998, Navas and Marhuenda, 2004), Murcia (González, 2015, Escudero and Martínez, 2013, González and Moreno, 2013), Cataluña (ERET, 2002), Andalucía (Marín, García and Sola, 2013), Castilla La Mancha (López and Palomares, 2012). This research has focused on various areas of interest: teachers and trainers, their background, training and identities; student socialisation and their relationships with each other and with teachers; methodologies employed in the workshop and the classroom; classroom norms and environment; the use of discipline to instil moral values and encourage citizenship; and organisational arrangements.

Some of this research has been gathered in monographs (Molpeceres, 2004; Marhuenda, 2006; González, 2015), but just as the educational administration has paid little attention to it in terms of provision, the academic world has also largely ignored the rupture that such programmes and measures have introduced in the secondary compulsory education system as well as in terms of the rearrangement of the VET system.

14 http://grupsderecerca.uab.cat/gret/en 
Debates about segregation vs. compensation, segmentation vs. inclusion, insecurity or dignity in these programmes are not simply academic, they are also political. The lack of stability and permanent funding for these programmes and the tendency to consider them a side issue are a cause for concern. This situation is exacerbated by the trends in the Spanish labour market, the lack of a proper guidance system, and a culture that does not value vocational training.

\section{Political views and changing trends: remedial systems, skill formation, or something else?}

This overview has provided a short history of the programmes we have studied over the past two decades, together with a closer look at the data in two regions where early school leaving rates are high and where the labour market attracts young people to the main economic sector (tourism). Along with the brief review of existing research, we can now make some final observations:

- The role of VET needs to be reviewed: is it a remedial or compensatory system, a second-hand route, or a proper route for skill formation and upgrading the qualifications of the country? Basic vocational education has been used for different purposes and, having overcome the bad reputation VET had gained in the 1970s, the trend now is again to consider VET as an option for low achievers. We believe this to be a mistake, particularly considering the importance of both academic and vocational education in the supply of skills for the national workforce. Academic provision at post-compulsory level is at almost twice the level of vocational provision.

- The rupture of the consensus around VET through the introduction of FPB also introduces a direct rupture of the comprehensive system, relocating such measures within vocational education. After extending the age of compulsory schooling to 16 , we have seen recent attempts to introduce a tracked system where segregation happens at 15 and vocational education is seen as the natural option for low achievers at an early age. What was once an exceptional choice has become the standard measure.

- There are contradictory drives both to facilitate further education and to dispatch young people from education provision. Opportunities to re-enter the education system for those registering for FPB will be harder unless the pathway is vocational, which will reinforce the segregation of the vocational track in post-compulsory education as well. Opportunities for those students to attain the GESO decrease, thus reinforcing the division among youth cohorts that we have seen in the past decade and a half.

- The sustainability of a vocational system without proper vocational planning and guidance is another concern. The fact that such programmes are funded on a yearly basis, in contrast with all other educational offers within the school system, makes it really hard to predict available provision, both in terms of location (which school) and type of vocational provision (which branch). The opportunities for students to choose to attend a different institution or, even more difficult, a particular vocational course reflecting their interests, will not increase with this funding mechanism, as the history of the past two decades has shown.

- The ability of the school system to satisfy all educational needs and incorporate new actors (municipalities and NGOs) in the provision of basic compulsory 
and vocational education - with or without proper acknowledgement - is also a cause for concern. The trend initiated 20 years ago allowing the entry of new actors as educational agents providing good educational opportunities for students has meant that burnout at school has diminished. This implies reschooling on one side and dispatching students after the age of 16 from the system on the other, without proper acknowledgement of what role other institutions like municipalities and NGOs, among other actors, can play in education.

- Transition pathways and mechanisms out of school present both opportunities and risks. While these pathways seem particularly relevant because the school has not been able to bring comprehensiveness to its full consequences, the chances of having second-rate options in economies ruled by labour markets based upon poorly qualified, low skilled and what we could call a low cost workforce imply a risk of social rupture instead of working towards social cohesion.

- The opposing tendencies toward vocationalisation or elitism in secondary education distort the picture. Most previous research confirms this, and the tendency is reinforced by the fact that teacher allocation and teacher training practices within the school sytem do not foster preparation for such special programmes or the assignment of the best prepared teachers to programmes where their capabilities are most needed. The implementation of FPB is about to go ahead without having secured the foundations upon which general (and not exceptional) measures should be based.

- The battle between personalisation and standardisation in education is also worth attention: the lack of balance between what the regulations express in terms of aims and their effects on the educational needs of young people. If students could remain in FPB for between two and four years, it would allow them to regain confidence, knowledge and skills. However, there are doubts about whether this really happens, because retention in such programmes for such long periods was not foreseen in the past two decades.

- A further question arising from the previous one is what students will do in their second year in FPB without colliding with qualifications in VET at postcompulsory level, even if they are qualification levels 2 or 3. Once more, politicians have decided to install a new programme without having foreseen the implications of such a development and how it fits with the existing system.

- A final concern we would like to highlight is the notion of work that is being taught in these programmes. Is it based on the concept of knowledge and skill that society is demanding in, for instance, the Strategy Europe 2020? Or will the labour market that both regions have experienced over the past four to five decades (tourism based on good weather and related sectors) be demanding a low-cost workforce from FPB, ready to obey and accept the working conditions provided.

All this suggests that FPB is not just one more amendment to educational provision for early school leavers, part of a long process over two decades, but seems to be a measure where the aims have been inverted, even if apparently remaining the same. We will have to track its implementation in order to assess how close or far its effects are from its normative definition. 


\section{References}

Adame, T. \& Salvà, F. (2010). Abandono escolar prematuro y transición a la vida activa en una economía turística: el caso de Baleares. Revista de Educación, $35,185-210$.

Aparisi, J. et al. (1998). El desarrollo psicosocial en el contexto educativo de los Programas de Garantía Social. Valencia: Universitat de València.

Casal, J., García, M., Merino, R. \& Quesada, M. (2004). Enquesta als joves de Catalunya 2002. Itineraris educatius, laborals i familiars Col-lecció Estudis (Vol. 13). Barcelona: Observatori Català de la Joventut.

Casal, J., García, M., Merino, R., \& Quesada, M. (2006a). Changes in forms of transition in contexts of informational capitalism. Papers, 79, 195-223.

Casal, J., García, M., Merino, R., \& Quesada, M. (2006b). Aportaciones teóricas y metodológicas a la sociología de la juventud desde la perspectiva de la transición. Papers, 79, 21-48.

Consejo Escolar del Estado (2014). Informe 2014 sobre el estado del sistema educativo. Curso 2012-2013. Madrid: Ministerio de Educación, Cultura y Deporte.

ERET. (2002). Prospectiva en torno a las grandes dimensiones de los programas de garantía social. Revista de Educación, 329, 487-510.

Escudero-Muñoz, J.M., Martínez-Domínguez, B. (2012). Las políticas de lucha contra el fracaso escolar: ¿programas especiales o cambios profundos del sistema y la comunicación? Revista de Educación, número extraordinario 1, 174-193.

González, M.T. (2015). La vulnerabilidad escolar y los Programas de Cualificación Profesional Inicial. Barcelona: Wolters Kluwer.

González, M.T., Moreno, M.A. (2013). El programa de Cualificación Profesional Inicial: Entre la integración o la marginación en los contextos organizativos donde se desarrolla. Revista de Investigación en Educación, 11, 118-133.

López, S. \& Palomares, A. (2012). La respuesta a la diversidad: de los Programas de Garantía Social hacia los Programas de Cualificación Profesional Inicial. Revista Española de Educación Comparada, 20, 249-274.

Marhuenda-Fluixà, F. (ed.). (2006). La cualificación profesional básica. Revista de Educación, $\mathrm{n}^{\circ}$ 341, 15-255.

Marhuenda-Fluixà, F., Navas-Saurin, A. (2004). Replantear la garantía social: aciertos y problemas de diez años de experiencias: manifiesto para la mejora de la formación para la inserción sociolaboral de jóvenes. Valencia: Servei de Publicacions de la Universitat de València.

Marín, J.A., García, M. \& Sola, J.M. (2013). Reflexión y análisis sobre los PCPI como medida de inclusión social y educativa en Andalucía (España). Revista Iberoamericana sobre Calidad, Eficacia y Cambio en Educación, 12 (1), 83102.

Ministerio de Educación, Cultura y Deporte. (2013). Objetivos educativos europeos y españoles. Estrategia Educación y Formación 2020. Informe español 2013. Madrid: Ministerio de Educación, Cultura y Deporte.

Molpeceres, M.A. (coord.)(2004). Identidades y formación para el trabajo. Montevideo: Cinterfor/OIT.

Palomares, A. \& López, S. (2013). Los Programas de Cualificación Profesional Inicial y la atención a la diversidad en Castilla-La Mancha. Enseñanza \& Teaching: Revista interuniversitaria de didáctica, 31, 23-44. 
Salvà-Mut, F., Oliver-Trobat, M.F. \& Comas-Forgas, R. (2014). Abandono escolar y desvinculación de la escuela: perspectiva del alumnado. Magis, Revista Internacional de Investigación en Educación, 6 (13), 129-142.

Salvà-Mut, F., Quintana-Murcia, E. \& Desmarais, D. (2015). Inclusion and exclusion factors in adult education of youth with a low educational level in Spain. European Journal of Research on the Education and Learning of Adults, 6 (1), 9-23.

Salvà, F. (2001). Formación y empleo de los/las jóvenes en Baleares: situación actual y orientaciones para la intervención con los colectivos con bajo nivel de cualificación . En Jóvenes más allá del empleo. Estructuras de apoyo a las transiciones de los jóvenes. España: Nau Llibres. P. 211 - 235.

Salvà, F. (dir.). (2002). Estudi sobre la inserció laboral dels joves amb baix nivell educatiu a Balears. Conselleria de Treball i Formació. Govern de les Illes Balears.

Salvà, F. (2013). Formación para el trabajo y jóvenes sin titulación en tiempos de crisis: balance y prospectiva. En Ruiz, C.; Navío, A.; Fandos, M.; Olmos, P. Formación para el trabajo en tiempo de crisis. Balance y prospectiva. Madrid: Tornapunta. P. 133-140.

Salvà, F. (dir.), Oliver, M.; Sureda, J., Casero, A., Adame, T. \& Comas, R. (2013). Abandono escolar prematuro y retorno al sistema educativo en Baleares: historias de vida del alumnado de la educación permanente de personas adultas. IRIE. Report of research, n. 2. 101 p.

Salvà-Mut, F. \& Sureda-Negre, J. (2012). L'utilisation des histoires de vie dans la recherche et l'innovation de l'école de la deuxième chance. En D. Desmarais, I. Fortier \& J. Rhéaume (eds.). Transformations de la modernité et pratiques (auto)biographiques. Québec: Presses de l'Université du Québec. P. 147-159.

Zacarés-González, J.J. (1998). Características psicosociales de los jóvenes participantes en los Programas de Garantía Social: una aproximación a partir de la metodología de cuestionario. En I. Martínez-Morales, F. MarhuendaFluixá (coords.), La experiencia educativa de los Programas de Garantía Social. Valencia: Servei de Publicacions de la Universitat de València.

Zacarés-González, J.J., Llinares-Insa, L.(2006). Experiencias positivas, identidad personal y significado del trabajo como elementos de optimización del desarrollo de los jóvenes. Lecciones aprendidas para los futuros Programas de Cualificación Profesional Inicial. Revista de Educación, 341, 123-148. 